\title{
Petit Basset Griffon Vendeen
}

National Cancer Institute

\section{Source}

National Cancer Institute. Petit Basset Griffon Vendeen. NCI Thesaurus. Code C53909.

The Petit Basset Griffon Vendeen is a small dog with an unkempt, wiry double coat with shaggy eyebrows, beard and mustache. It comes in white with markings in any of the following colors: black, orange, yellow, tri-color and grizzle. It is about 50\% longer than tall. The tail tapers and is carried high and alert. Height: 13-15 inches $(34-38 \mathrm{~cm}$.) Weight: $31-40$ pounds (14-18 kg.) 